\title{
Land and Racial Wealth Inequality
}

\author{
By Melinda C. MilleR ${ }^{\text {米 }}$
}

During the 1890s, Cherokee cattleman Zack Foreman struck a deal with the Kansas City Southern Railroad. If Foreman would prepare the roadbed, they would lay the steel. With large cattle herds and his own rail line, he became one of the wealthiest men in Indian Territory. [1] This wealth was exceptional because Foreman had been born a slave. 즐 Since emancipation, the wealth of former slaves and their descendents has greatly lagged behind that of whites. Robert Higgs $(1977,1982)$ found that black total property holdings were just $1 / 36$ those of whites in $1880,1 / 26$ in $1890,1 / 23$ in 1900 , and $1 / 16$ in 1910 3 Although an income gap existed, it was much smaller than the wealth gap at $1 / 4$ in 1867 and 7/20 in 1900. Despite large gains in black income during the past century, the racial wealth gap remains large today and continues to dwarf the income gap. While black households earn approximately half the income of white households, they hold only one-tenth to one-fifth the wealth of white households (Robert Barsky et al. 2002).

Explanations for the persistent and large racial wealth gap largely fall into two categories. First,

*Economic Growth Center, Yale University, PO Box 208269, New Haven, CT 06520-8269 (e-mail: mmiller@ usna.edu). I thank Warren Whatley, Ben Chabot, Martha Bailey, and seminar participants at the University of Michigan, Yale University, the US Naval Academy, the NBER DAE Summer Institute, and the Cliometrics Society for their suggestions. I would like to thank the National Science Foundation and Economic History Association for their generous support.

${ }^{1}$ The Cherokee Nation was located in Indian Territory, which by the Civil War comprised the land that is now the state of Oklahoma. Its western half became Oklahoma Territory in 1890. The eastern half remained Indian Territory until 1907, when the Oklahoma and Indian Territories merged to form the state of Oklahoma.

${ }^{2}$ J. J. Cape Interview, GFPHC, 88:56-58.

${ }^{3}$ Higgs $(1977,1982)$ uses data from Georgia property tax returns. Robert A. Margo (1984) extends Higgs's work with wealth information for Arkansas, Louisiana, North Carolina, and Virginia. He finds a similar temporal trend to that of Higgs - blacks accumulated property at a faster rate than whites, but the black-white wealth gap remained large on the eve of World War I. However, Margo's evidence suggests that black wealth grew at a slower rate than Higgs calculated. racially discriminatory policies in credit markets, labor markets, school finance, and other institutions may have inhibited the ability of blacks to earn income and accumulate wealth (Melvin L. Oliver and Thomas Shapiro 1995; William J. Collins and Robert A. Margo 2001). And, second, the effect of such policies may have amplified the impact of an alternate source of the racial wealth gap-low initial levels of black wealth. During slavery, law and custom prevented most slaves from owning property or other assets. After the Thirteenth Amendment abolished slavery, emancipation grants of "forty acres and a mule" were proposed to remedy the freedmen's lack of capital. They never came to fruition, thus ensuring that former slaves entered freedom with little to no wealth, lagging substantially behind whites (Stephen J. DeCanio 1979).

Isolating the relative contribution of each explanation to the black-white wealth gap can be difficult without variation in the legal treatment of freed slaves. This paper exploits a plausibly exogenous variation in the policies of the Cherokee Nation and the southern United States to identify the impact of free land on the racial wealth gap in 1880 and 1900.4 Like other freed slaves in the Cherokee Nation, Zack Foreman possessed a key advantage over blacks in the southern United States: the option of claiming free land. The Cherokee Nation joined the Confederacy in 1861 and was forced during postwar negotiations to declare its former slaves, who were of African descent, citizens with "all the rights of native Cherokees." the laws of the Nation, all citizens, including the freed slaves, were guaranteed the right to claim and improve any unused land in the Nation's

\footnotetext{
${ }^{4}$ I define the South as states that joined the Confederacy: Alabama, Arkansas, Florida, Georgia, Louisiana, Mississippi, North Carolina, South Carolina, Tennessee, Texas, and Virginia.

5 John Marshall famously declared the Cherokee Nation a "denominated domestic dependent nation" in Cherokee Nation v. Georgia, 30 US 1 (1831). Because of this semiautonomous status, the Cherokee Nation negotiated its own peace settlement with the United States that was separate from the agreement reached with the southern states.
} 
public domain. ${ }^{0}$ Armed with farming supplies provided by the Department of Interior, many Cherokee freedmen abandoned sharecropping or wage labor to claim their own land after the treaty went into effect.

\section{Background}

The Cherokee freedmen's access to free land may have helped them escape a pernicious consequence of slavery-persistently low levels of wealth relative to people who had not been slaves. DeCanio (1979) estimated that allocating each freedmen head of household "forty acres and a mule" would have dramatically increased blacks' starting average wealth level to 60 percent that of whites. Empirical evidence suggests that the Cherokee freedmen's initial wealth advantages over southern freedmen could have been partially transmitted to the next generation. James R. Kearl and Clayne L. Pope (1986) found the correlation between fathers' and sons' wealth to range from 0.18 to 0.35 between 1855 and 1900. Avery M. Guest, Nancy S. Landale, and James C. McCann (1989) found a great deal of occupational inheritance for father-son pairs in 1900. A quarter of laborers, for example, had laborers as fathers, and 59.9 percent of farmers had farmer fathers. Joseph Ferrie (2005) collected a linked census sample of fathers in 1880 and sons in 1900; he found that 29.5 percent of unskilled laborers had unskilled laborers as sons, while 46.6 percent of farmers had farmers as sons.

Theoretical models suggest two channels through which the Cherokee freedmen's property acquisition could have had a long-run effect on their levels of wealth relative to both nonblacks and the descendents of southern slaves. Thomas Piketty (2000) showed that high intergenerational wealth correlations could result from parents' ability to bequeath their children an inheritance. As Gary S. Becker and Nigel Tomes $(1979,1986)$ modeled, the productive ability of one generation may be influenced by that of the previous generation. Black farm owners would have gained knowledge of farm management practices, business contacts, and

\footnotetext{
${ }^{6}$ After a Cherokee citizen claimed land, he held heritable usufructuary rights; the land could be sold, used as collateral, bequeathed, or improved upon. It could not be sold to non-Cherokee citizens. See Khaled J. Bloom (2002).
}

knowledge of local credit markets. The transmission of this endowment to their children would likely increase their productive abilities. David N. Laband and Bernard F. Lentz (1983) found that farmers who were the children of farmers earned a premium over other farmers, suggesting that family background and experience can positively influence farming productivity.

\section{Data}

To infer the effect of free land access on the wealth of former slaves and their descendents, I use data from the 1880 Cherokee Nation Census, the 1880 United States Census Agricultural Schedules, and the 1900 United States Census. The 1880 Cherokee Census was collected by the Cherokee government in 1880. I It recorded both demographic and agricultural data for each family. The key variables for this analysis include the amount of land and livestock owned by each family. I linked freedmen from the 1880 Cherokee Census to the 1900 United States Census to obtain a sample of former slaves who had been treated with access to free land. To compare the Cherokee Nation to the southern states, I use the sample collected by Roger Ransom and Richard Sutch for their book One Kind of Freedom (2001). This sample of farmers in 1880 was constructed by matching farmers listed on the 1880 United States Agricultural Schedules to their respective entries on the 1880 Population Schedules. ${ }^{\mathbb{Q}}$ For each farm, the schedules include measures of farm size and

\footnotetext{
${ }^{7}$ Cherokee citizens were not included in the population schedules of the United States Census until 1900. They were considered "Indians not taxed" and excluded from US census enumerations.

${ }^{8}$ A total of 789 freedmen were linked from the 1880 Cherokee Census. When their 1,875 family members are included, the linked sample contains 2,664 individuals and 470 households. The linkage rate was 84 percent.

9 The agricultural and population schedules required matching because, unlike the 1880 Cherokee Census, the 1880 United States Census recorded household demographic data on one schedule (the population schedules) and farming information on separate agricultural schedules. Because the agricultural schedules contain only the name and not the race of the farmer, farmers must be linked from their agricultural schedule to their population schedule in order to identify a farmer's race. Details of the rigorous procedures Ransom and Sutch used to ensure that matches were made correctly and that data were entered correctly are documented in "Appendix G: Data Appendix" of One Kind of Freedom. Farms in Arkansas were not included in
} 
livestock ownership. Additionally, the tenure status of the farmer is listed. ${ }^{10}$ For 1900 , I used a sample of rural southern households drawn from the 1900 IPUMS with Indian oversample. I focus on two measures of economic status from the 1900 United States Census. For each person, the census records occupation. Additionally, for each household, the census records if the home is owned or rented.

\section{Empirical Results and Framework}

Economic theory suggests that the gap between black and nonblack wealth levels would have been smaller if former slaves had received free land when emancipated. That is, for a given measure of mean or median wealth $\bar{K}$, the racial gap would be smaller in the Cherokee Nation that in the South:

$$
\bar{K}_{\text {non-black }}^{\text {South }}-\bar{K}_{\text {black }}^{\text {South }}>\bar{K}_{\text {non-black }}^{\text {Cheroke Nation }}-\bar{K}_{\text {black }}^{\text {Cheroee Nation }}
$$

Additionally, blacks in the South should have lower absolute levels of mean wealth than blacks in the Cherokee Nation:

$$
\bar{K}_{\text {black }}^{\text {South }}<\bar{K}_{\text {black }}^{\text {Cheroke Nation }}
$$

To estimate the difference in the racial wealth gaps for a given year, I estimate a specification of the general form

$$
\begin{aligned}
K_{i}= & \beta_{0}+\beta_{1} \text { Black }_{i}+\beta_{2} C N_{i} \\
& +\beta_{3}\left(\text { Black }_{i} \times C N_{i}\right)+\mathbf{X}_{i} \gamma+\varepsilon_{i},
\end{aligned}
$$

where $K_{i}$ denotes a measure of wealth for a given household $i$. The vector $\mathbf{X}_{\mathbf{i}}$ includes various controls. For the 1880 analysis, these include farmer's literacy, age, $\mathrm{age}^{2}$, and controls for the soil type on which the farm is located.11] In 1900, the controls include literacy, gender, age, and age ${ }^{2}$

this sample. Therefore, any analysis using these data will exclude Arkansas.

${ }^{10}$ Farms of various types, including owners, fixed renters, and sharecroppers, were enumerated on the agricultural schedules. Only owners actually owned the land on which their farm was located.

${ }^{11}$ Soil types are taken from the soil map included in Tenth Census of the United States, Volume 5, Report on Cotton Production in the United States (1880). Because cotton was grown in Indian Territory, the map includes soil types for the Cherokee Nation. of the household head, and number of people in the household. Black is an indicator variable equal to one if a farmer's or household head's race is black, and takes the value of zero otherwise. The $\mathrm{CN}$ variable is one if a household is located in the Cherokee Nation and zero if in the southern United States. The coefficient on the interaction term, $\beta_{3}$, measures the difference in the gaps. Since the omitted category is a nonblack in the South,

$$
\begin{aligned}
\beta_{3}=\left\{E\left[K_{i} \mid \text { black }=0, C N=0, X_{i}\right]\right. \\
\left.-E\left[K_{i} \mid \text { black }=1, C N=0, X_{i}\right]\right\} \\
-\left\{E\left[K_{i} \mid \text { black }=0, C N=1, X_{i}\right]\right. \\
\left.-E\left[K_{i} \mid \text { black }=1, C N=1, X_{i}\right]\right\} .
\end{aligned}
$$

A positive and significant estimate of $\beta_{3}$ suggests that the racial wealth gap for farmers was smaller in the Cherokee Nation than in the United States for the outcome of interest.

\section{A. Wealth Inequality in 1800}

To test the hypothesis that racial wealth inequality was smaller in the Cherokee Nation than in the South, I use farm-level data for male heads of households from the 1880 Cherokee Census and the 1880 agricultural sample. I assume that tenant and sharecropping farmers own no acreage. Black farmers in the Cherokee Nation owned 24.68 acres of land on average, which is more than three times as much as the 9.37 that southern black farmers owned. In the Cherokee Nation, freedmen farmers owned approximately two-thirds the land of nonblacks on average. Southern black farmers lagged much farther behind and had only 17 percent the acreage of white farmers. I estimate equation (1) where $K_{i}$ is farm acreage owned. Due to the large proportion of farmers who owned no land, I use median regression on levels. Results are reported in panel A of Table 1. In both the baseline (column 1) and fully controlled (column 2) specifications, the interaction term is positive and statistically significant at approximately the 1 percent level. The interaction term is also large in magnitude, and access to free land is associated with a shrinking of the racial gap in median farm size between 15.92 and 18.00 acres. The median black farm in the South is also 
Table 1-Estimates of the Racial Wealth GaP

\begin{tabular}{|c|c|c|c|c|}
\hline & $\begin{array}{l}\text { Acreage } \\
\text { (1) }\end{array}$ & $\begin{array}{l}\text { Acreage } \\
(2)\end{array}$ & $\begin{array}{c}\text { Livestock (1880\$) } \\
\text { (3) }\end{array}$ & $\begin{array}{c}\text { Livestock }(1880 \$) \\
(4)\end{array}$ \\
\hline \multicolumn{5}{|l|}{ Panel A. 1880} \\
\hline Black $\times \mathrm{CN}$ & $\begin{array}{l}18.00 * * * \\
{[2.04]}\end{array}$ & $\begin{array}{l}15.92 * * * \\
{[1.32]}\end{array}$ & $\begin{array}{l}41.61 * * * \\
{[10.17]}\end{array}$ & $\begin{array}{l}45.54 * * * \\
{[10.64]}\end{array}$ \\
\hline \multirow[t]{2}{*}{$R^{2}$} & $\begin{array}{c}12,123 \\
0.0902\end{array}$ & $\begin{array}{c}12,015 \\
0.0984\end{array}$ & $\begin{array}{c}12,123 \\
0.07\end{array}$ & $\begin{array}{c}12,015 \\
0.11\end{array}$ \\
\hline & $\begin{array}{c}\text { Home ownership } \\
=1\end{array}$ & $\begin{array}{c}\text { Home ownership } \\
=1\end{array}$ & $\begin{array}{l}\text { Farmer } \\
=1\end{array}$ & $\begin{array}{l}\text { Farmer } \\
=1\end{array}$ \\
\hline \multicolumn{5}{|l|}{ Panel B. 1900} \\
\hline Black $\times \mathrm{CN}$ & $\begin{array}{l}-0.35^{* * * *} \\
{[0.02]}\end{array}$ & $\begin{array}{l}-0.34 * * * \\
{[0.07]}\end{array}$ & $\begin{array}{l}-0.14^{* * * *} \\
{[0.02]}\end{array}$ & $\begin{array}{l}-0.21 * * * \\
{[0.06]}\end{array}$ \\
\hline $\begin{array}{l}\text { Observations } \\
R^{2}\end{array}$ & $\begin{array}{c}33,703 \\
0.1\end{array}$ & $\begin{array}{c}33,664 \\
0.19\end{array}$ & $\begin{array}{c}33,703 \\
0.01\end{array}$ & $\begin{array}{c}33,664 \\
0.08\end{array}$ \\
\hline
\end{tabular}

Notes: Standard errors are reported in brackets. For panel A, the sample includes male heads of household in the Cherokee Nation and agricultural census sample. Controls in columns 2 and 4 include farmer's literacy, age, age ${ }^{2}$, and controls for the soil type. Results for median regression are reported. For panel B, the sample includes heads of household in the Cherokee Nation and rural South. Controls in columns 2 and 4 include literacy, gender, age, and age ${ }^{2}$ of the household head, and number of people in the household. Marginal effects of probit regression are reported.

*** Significant at the 1 percent level.

Source: Author calculations.

statistically significantly smaller than the median black Cherokee farm. The median Cherokee freedmen farmer owned 28 more acres of land than the median black farmer in the South in the fully controlled specification.

While Cherokee freedmen were able to claim land, they were not granted the second part of the famous saying: a mule. If they were able to successfully farm land and accumulate wealth, then they should have been able to accumulate livestock wealth to remedy their initial lack of work animals. I estimate equation (1) where $K_{i}$ is total value of livestock on a farm. ${ }^{12}$ Blacks in the Cherokee Nation consistently have statistically significantly higher levels of livestock wealth than blacks in the South. In the baseline specification (column 3), their wealth is higher by $\$ 190$. When controls are included in column 4 , the wealth advantages grow dramatically, to over $\$ 300$. The estimated wealth gap is also significantly smaller in the Cherokee Nation than in the South, and varies from \$41 to $\$ 45$.

\footnotetext{
${ }^{12}$ This is calculated as the summed values of all horses, cattle, mules, sheep, and swine in 1880 dollars.
}

\section{B. Wealth Inequality in 1900}

To examine wealth inequality in 1900 , I combined the linked sample of Cherokee freedmen with a sample of rural southern households drawn from the 1900 IPUMS with Indian oversample. To estimate the relative racial wealth inequality in the Cherokee Nation and the South, I focus on a key measure of wealth acquisition: home ownership. I estimate a variant of equation (1) using the probit specification

$$
\text { (2) } \begin{aligned}
\operatorname{Pr}\left(K_{i}=1\right)=\Phi & \left(\beta_{o}+\beta_{1} \text { Black }_{i}+\beta_{2} C N_{i}\right. \\
& +\beta_{3}\left(\text { Black }_{i} \times C N_{i}\right) \\
& \left.+\mathbf{X}_{i} \gamma+\varepsilon_{i}\right),
\end{aligned}
$$

where $K_{i}$ takes a value of one if a household is reported as owning its home.

Estimates for the difference in the homeownership gap are in panel B. In both specifications racial wealth inequality remains lower in the Cherokee Nation than in the South. The difference in the racial homeownership rates between the two areas is 35 percent for the baseline specification, which is both large and 
statistically significant. Additionally, the Cherokee freedmen are absolutely better off than southern freedmen and have significantly higher estimated home ownership rates in both specifications. An alternate measure of economic success is occupation. I repeat the estimation above with the dependent variable taking on a value of one if the head of household is a farmer. The estimated coefficients suggest that blacks in the Cherokee Nation are more likely to be farmers than southern freedmen are. Additionally, the racial occupation gap is between 14 and 22 percent smaller in the Cherokee Nation than in the South. Southern blacks appear to face obstacles in becoming farmers and are 10 to 13 percent less likely to become farmers than southern whites.

\section{Conclusions}

How would the distribution of free land have affected the large racial wealth gap that has persisted for almost a century and a half? In this paper, I developed an empirical strategy to exploit a plausibly exogenous variation in policies of the Cherokee Nation and the southern states to identify the impact of free land on racial wealth inequality. After documenting evidence that racial wealth inequality was similar in the Cherokee Nation and the South on the eve of the Civil War, I then examined various measures of wealth and status in 1880 and 1900. I found that racial wealth inequality was much lower in the Cherokee Nation than in the South in 1880. Not only were the racial gaps smaller, but Cherokee freedmen were also absolutely better off than southern freedmen. I then compared a sample of blacks in the Cherokee Nation who were linked from 1880 to 1900 to blacks in the South. I again found strong evidence that racial wealth inequality was lower in the Cherokee Nation that in the South. These results strongly suggest that free land could have reduced racial wealth inequality.

\section{REFERENCES}

Barsky, Robert, John Bound, Kerwin Kofi Charles, and Joseph P. Lupton. 2002. "Accounting for the Black-White Wealth Gap: A Nonparametric Approach." Journal of the American Statistical Association, 97(459): 663-73.
Becker, Gary S., and Nigel Tomes. 1979. "An Equilibrium Theory of the Distribution of Income and Intergenerational Mobility." Journal of Political Economy, 87(6): 1153-89.

Becker, Gary S., and Nigel Tomes. 1986. "Human Capital and the Rise and Fall of Families." Journal of Labor Economics, 4(3): S1-39.

Bloom, Khaled J. 2002. "An American Tragedy of the Commons: Land and Labor in the Cherokee Nation, 1870-1900." Agricultural History, 76(3): 497-523.

Cape, J. J., Interview. Grant Foreman Pioneer History Collection, 88: 56-58. Archives and Manuscript Division, Oklahoma City Historical Society.

Collins, William J., and Robert A. Margo. 2001. "Race and Home Ownership: A Century-Long View." Explorations in Economic History, 38(1): 68-92.

DeCanio, Stephen J. 1979. "Accumulation and Discrimination in the Postbellum South." Explorations in Economic History, 16(2): 182206.

Ferrie, Joseph P. 1995. "A New Sample of Americans Linked from the 1850 Public Use Micro Sample of the Federal Census of Population to the 1860 Federal Census Manuscript Schedules." National Bureau of Economic Research Historical Working Paper 071.

Guest, Avery M., Nancy S. Landale, and James C. Mccann. 1989. "Intergenerational Occupational Mobility in the Late 19th Century United States." Social Forces, 68(2): 351-78.

Higgs, Robert. 1977. Competition and Coercion: Blacks in the American Economy, 1865-1914. New York: Cambridge University Press.

Higgs, Robert. 1982. "Accumulation of Property by Southern Blacks before World War I." American Economic Review, 72(4): 725-37.

Jianakoplos, Nancy Ammon, and Paul L. Menchik. 1997. "Wealth Mobility." Review of Economics and Statistics, 79(1): 18-31.

Kearl, James R., and Clayne L. Pope. 1986. "Unobservable Family and Individual Contributions to the Distributions of Income and Wealth." Journal of Labor Economics, 4(3): S48-79.

Laband, David N., and Bernard F. Lentz. 1983. "Occupational Inheritance in Agriculture." American Journal of Agricultural Economics, 65(2): 311-14.

Margo, Robert A. 1984. "Accumulation of Property by Southern Blacks before World War I: 
Comment and Further Evidence." American Economic Review, 74(4): 768-76.

Oliver, Melvin L., and Thomas M. Shapiro. 1995. Black Wealth/White Wealth: A New Perspective on Racial Inequality. New York: Routledge.

Piketty, Thomas. 2000. "Theories of Persistent Inequality and Intergenerational Mobility." In Handbook of Income Distribution, Vol. 1. Handbooks in Economics, Vol. 16, ed. A. B. Atkinson and F. Bourguignon, 429-76. New York: Elsevier.

Ransom, Roger L., and Richard Sutch. 2001. One Kind of Freedom: The Economic Consequences of Emancipation. New York: Cambridge University Press.

Ruggles, Steven, Matthew Sobek, Trent Alexander,
Catherine A. Fitch, Ronald Goeken, Patricia Kelly Hall, Miriam King, and Chad Ronnander. Integrated Public Use Microdata Series: Version 5.0 [Machine-Readable Database]. Minneapolis, MN: Minnesota Population Center [producer and distributor], 2004 (accessed June 2010).

Sutch, Richard, and Roger Ransom. Southern Agricultural Households in the United States, 1880 [Computer file]. Berkeley, CA: University of California Berkeley, Institute of Business and Economic Research and Center for Research in Management Science [producer], 1990. Ann Arbor, MI: Inter-University Consortium for Political and Social Research [distributor], 2007-09-19 (accessed November 2007). 